\section{Immunohistochemical study of doublecortin and nucleostemin in canine brain}

\author{
E. De Nevi, ${ }^{1}$ P. Marco-Salazar, ${ }^{1}$ \\ D. Fondevila, ${ }^{1,2}$ E. Blasco, ${ }^{1,2}$ L. Pérez, ${ }^{2}$ \\ M. Pumarola ${ }^{1,2}$
}

1Department of Animal Medicine and Surgery, Faculty of Veterinary Medicine, Universitat Autònoma de Barcelona; ${ }^{2}$ Center of Animal Biotechnology and Gene Therapy, Universitat Autònoma de Barcelona, Bellaterra (Cerdanyola del Vallès), Barcelona, Spain

\begin{abstract}
Finding a marker of neural stem cells remains a medical research priority. It was reported that the proteins doublecortin and nucleostemin were related with stem/progenitor cells in central nervous system. The aim of the present immunohistochemical study was to evaluate the expression of these proteins and their pattern of distribution in canine brain, including age-related changes, and in non-nervous tissues. We found that doublecortin had a more specific expression pattern, related with neurogenesis and neuronal migration, while nucleostemin was expressed in most cells of almost every tissue studied. The immunolabeling of both proteins decreased with age. We may conclude that nucleostemin is not a specific marker of stem/progenitor cells in the dog. Doublecortin, however, is not an exclusive marker of neural stem cells, but also of neuronal precursors.
\end{abstract}

\section{Introduction}

In the central nervous system (CNS) of mammalian adult brain neurogenesis takes place mainly in two germinal zones: the subgranular zone (SGZ) of the hippocampal dentate gyrus and the subventricular zone (SVZ) of the lateral ventricle wall. ${ }^{1}$ In these germinal regions it has been demonstrated that neural stem cells (NSC), with characteristics of astrocytes, generate transit-amplifying cells which in turn divide to generate neuroblasts and glial cell precursors. ${ }^{2,3}$

SVZ and SGZ astrocytes are a heterogeneous cellular population and it remains unclear whether only a subpopulation of them are NSC, or whether the neurogenic potential is latent in all astrocytes throughout the CNS, with inhibitory signals in the microenvironment preventing these cells from producing neurons. ${ }^{4,5}$ In this regard, the peculiar histoar- chitecture of the NSC niche includes abundant cell-cell interactions, an enriched extracellular matrix, and extensive vascularity, with NSC and transit-amplifying cells contacting the vessels walls in place of astrocyte endfeet and pericytes. ${ }^{5,6}$ Currently, investigation of NSC is impeded by the lack of a specific marker that could allow identifying these cells and, consequently, regulating neurogenesis, as occurs after brain injury. Doublecortin (DCX) is a microtubule-associated protein ${ }^{7}$ implicated in neurogenesis and in the radial and tangential migration of neuroblasts during development of the brain. ${ }^{8}$ Some studies have shown its expression in mature neurons as well. Therefore it has been hypothesized that it could also play a role in structural plasticity such as neurite outgrowth and synaptogenesis. ${ }^{9-11}$ With some differences among the investigated species, its expression has been reported in the germinal zones, neocortex, paleocortex, striatum, corpus callosum and septal nuclei. ${ }^{8,12-16}$

Nucleostemin (NS) is a nucleolar protein discovered in $2002^{17}$ that belongs to the YIqF/YawG GTPase family. ${ }^{18}$ It seems to be involved in cellular proliferation, ${ }^{19}$ maintenance of telomere length, ${ }^{20}$ and ribosome biogenesis. ${ }^{21}$ In a pioneering study, Tsai and McKay, demonstrated that the protein was expressed in murine embryonic CNS NSC and that it was abruptly down-regulated during differentiation prior to terminal cell division. ${ }^{17}$ However, more recent investigations have shown that NS could be found even in neoplastic tissues, both rodent and human. ${ }^{22-30}$

To our knowledge, except for some studies to detect DCX conducted in canine hippocampus, ${ }^{31-33} \mathrm{NS}$ and DCX expression has not previously been described in canine tissues. Study of the protein tissue presence is the first step in the discovery of a putative stem cells marker, so the primary aim of this preliminary report was to detect these proteins by immunohistochemistry (IHC) in canine brain and to describe their distribution and age-related changes. Furthermore we evaluated expression of both markers in mature and proliferating non-nervous tissues.

\section{Materials and Methods}

\section{Samples}

Samples were obtained from the Banc de Teixits Animals de Catalunya and from the Veterinary Pathology Service of the Universitat Autònoma de Barcelona (Table 1).

For brain mapping we chose 3 dogs representing different stages of life: young (3 months), adult (5 years) and geriatric (17 years). These animals had not shown any neurological signs and the histopathological study
Correspondence: Dr. Martí Pumarola, Department of Animal Medicine and Surgery, Faculty of Veterinary Medicine, Universitat Autònoma de Barcelona, 08193 Bellaterra (Cerdanyola del Vallès), Barcelona, Spain. Tel. +34.93.5811421 - Fax: +34.93.5813142. E-mail: marti.pumarola@uab.cat

Key words: nucleostemin, doublecortin, stem cells, dog brain, aging.

Contributions: EDN, collection of samples, processing, sectioning and immunohistochemical part of the work; PM-S, EB, MDP, helping in technical part; EDN, DF, evaluation of results and discussion; EDN, MP, work design, results discussion and manuscript writing.

Conflict of interests: the authors declare no conflict of interests.

Received for publication: 3 August 2012. Accepted for publication: 18 December 2012.

This work is licensed under a Creative Commons Attribution NonCommercial 3.0 License (CC BYNC 3.0).

\section{(C) Copyright E. De Nevi et al., 2013}

Licensee PAGEPress, Italy

European Journal of Histochemistry 2013; 57:e9 doi:10.4081/ejh.2013.e9

of their brain had not revealed nervous lesions. Six representative transversal sections from frontal brain area to caudal medulla oblongata were selected (Tables 2 and 3). We also included other non-nervous samples and proliferating tissues such as testicle and skin samples with a process of a second intention healing showing epidermal regeneration and granulation tissue (Table 1).

\section{Immunohistochemistry}

Formalin-fixed paraffin-embedded tissue sections $(3 \mu \mathrm{m})$ were deparaffinized with xylene, rehydrated in descending concentrations of ethanol, and boiled in bain-marie (96$\left.98^{\circ} \mathrm{C}\right)$ for $20 \mathrm{~min}$ in citrate buffer $(0.01 \mathrm{M}, \mathrm{pH}$ 6.0 ). Endogenous peroxidase activity was suppressed with $3 \% \mathrm{H}_{2} \mathrm{O}_{2}$ for $40 \mathrm{~min}$. Slides were serum-blocked with normal rabbit (NS) and goat (DCX, betaIII-tubulin, NeuN, GFAP) serum for $1 \mathrm{~h}$. As primary antibodies we used a rabbit anti-doublecortin (Abcam, Ab18723, Cambridge, UK), diluted 1 to 1000 , a goat antinucleostemin (R\&D systems, AF1638, Abingdon, UK), diluted 1 to 100, a mouse antitubulin beta III isoform (Millipore, MAB1637, Darmstadt, Germany), diluted 1 to 200 , a mouse anti-NeuN (Millipore, MAB377), diluted 1 to 100 , and a rabbit anti-GFAP (Dako, Z0334, Denmark), diluted 1 to 3000 . Immunohistochemistry was carried out with the AvidinBiotin peroxidase Complex (ABC) method for 
NS and EnVisionTM for DCX, beta III-tubulin, NeuN and GFAP (Dako EnVision+ System-HRP, Denmark). As chromogen substrate $3,3^{\text {c }}$ diaminobenzidine was used. Counterstaining was performed with hematoxylin. The negative control section from the same specimens was identically processed, replacing the primary antibody with irrelevant IgG of the same species class and concentration as the primary antibody.

\section{Quantification and semi-quantification of data}

Microscopic images were obtained with a Leica DFC 480 digital camera (Leica Microsystems Ltd., Heerbrugg, St. Gallen, Switzerland) coupled with a microscope (Leica DM6000B). For the reconstruction of the different anatomical areas, the photos were processed with the software Adobe ${ }^{\circledR}$ Photoshop ${ }^{\circledR}$ CS5.

DCX quantitative evaluation was conducted with the image processing program Image $\mathbf{J}$ (U. S. National Institutes of Health, Bethesda, Maryland, USA), calculating the percentage of positive stained area for each region. The immunolabeling intensity was scored as negative (-), weak/moderate (I), or strong (II). For NS evaluation we considered the presence $(+)$ or lack (-) of immunostaining and its intensity as weak/moderate (I) or strong (II).

\section{Results}

\section{Doublecortin brain mapping}

DCX immunostained cells (DCX+) appeared as irregular cells having a small cellular body and short extensions and showing a diffuse cytoplasmic granular staining (Figure 1A). $\mathrm{DCX}^{+}$cells did not react against other neural markers as BetaIII-Tubulin, NeuN and GFAP (data not shown). The brain areas with $\mathrm{DCX}^{+}$ cells were found to be mainly concentrated in the cerebrum and the cerebellum. In the cerebrum the subventircular zone (SVZ) of lateral ventricles, the subgranular zone (SGZ), and granular layers of the Gyrus dentatus of the hippocampus showed the greatest number of $\mathrm{DCX}^{+}$cells. The number of $\mathrm{DCX}^{+}$cells decreased in cortical areas such as Layer II of the neocortex, where they showed a mature neuronal morphology (Figure 1B), and Layer II of the paleocortex (Figure 1C). Basal nuclei such as caudate and putamen nuclei also contained $\mathrm{DCX}^{+}$cells. In the cerebellum the external germinal layer and cortical molecular layer showed the greatest number of $\mathrm{DCX}^{+}$cells (Figure 1D), with their number decreasing at the level of the cortical granular layer. Scattered $\mathrm{DCX}^{+}$cells were detected in thalamic nuclei. Considering the age of the dogs, the
Table 1. Animals and tissues included in the study.

\begin{tabular}{lccc} 
Breed & Age & Sex & Sample \\
Maltese & 3 months & Female & Brain \\
Miniature Schnauzer & 5 years & Male & Brain \\
\hline Mixed-breed & 17 years & Male & Brain \\
Boxer & 8 years & Female & Liver \\
\hline Spanish Mastiff & 3 years & Male & Skeletal muscle \\
Beagle & 5 years & Male & Cardiac muscle \\
& & & Testicle \\
\hline Beagle & 8 years & Male & Granulation tissue \\
\hline
\end{tabular}

Table 2. Doublecortin expression and immunostain intensity in canine brain.

\begin{tabular}{|c|c|c|c|}
\hline & Young dog & Adult dog & Geriatric dog \\
\hline \multicolumn{4}{|l|}{ Cerebrum } \\
\hline $\begin{array}{l}\text { Frontal neocortex } \\
\text { Molecular layer } \\
\text { Layer II } \\
\text { Layers III - VI } \\
\text { Corpus callosum } \\
\text { Corona radiata } \\
\text { Subventricular zone }\end{array}$ & $\begin{array}{c}\text { Neg } \\
2.9 \%(\mathrm{I}) \\
\mathrm{Neg} \\
\mathrm{Neg} \\
\mathrm{Neg} \\
7.82 \%^{*}(\mathrm{II})\end{array}$ & $\begin{array}{c}\text { Neg } \\
\text { Neg } \\
\text { Neg } \\
\text { Neg } \\
\text { Neg } \\
6.25 \% *(I I)\end{array}$ & $\begin{array}{c}\text { Neg } \\
\text { Neg } \\
\text { Neg } \\
\text { Neg } \\
\text { Neg } \\
1.19 \% *(I I)\end{array}$ \\
\hline $\begin{array}{l}\text { Basal nuclei } \\
\text { Caudate nucleus } \\
\text { Putamen nucleus } \\
\text { Septal nuclei }\end{array}$ & $\begin{array}{c}3.1 \%(\mathrm{I}) \\
1.7 \%(\mathrm{I}) \\
2.1 \%(\mathrm{II}-\mathrm{I})\end{array}$ & $\begin{array}{l}2 \%(\mathrm{II}) \\
\mathrm{Neg} \\
6.2 \%(\mathrm{I})\end{array}$ & $\begin{array}{l}\text { Neg } \\
\text { Neg } \\
\text { Neg }\end{array}$ \\
\hline $\begin{array}{l}\text { Paleocortex } \\
\text { Molecular layer } \\
\text { Layer II }\end{array}$ & $\begin{array}{c}\mathrm{Neg} \\
17.6 \% \text { (II) }\end{array}$ & $\begin{array}{c}\mathrm{Neg} \\
0.8 \%(\mathrm{I})\end{array}$ & $\begin{array}{l}\text { Neg } \\
\text { Neg }\end{array}$ \\
\hline $\begin{array}{l}\text { Piriform lobe } \\
\text { Molecular layer } \\
\text { Layer II } \\
\text { Archicortex } \\
\text { Ammon's Horn } \\
\text { Dentate gyrus } \\
\text { Subgranular layer } \\
\text { Granular layer } \\
\text { Hilus }\end{array}$ & $\begin{array}{c}\text { Neg } \\
65.3 \%(\mathrm{I}) \\
5.4 \%(\mathrm{I}) \\
3.9 \%(\mathrm{I})\end{array}$ & $\begin{array}{l}\text { Neg } \\
0.8 \%(\mathrm{I}) \\
\text { Neg } \\
9.4 \% \text { (II) } \\
\text { Neg } \\
\text { Neg }\end{array}$ & $\begin{array}{c}\mathrm{Neg} \\
\\
\mathrm{Neg} \\
\mathrm{Ne} \\
\mathrm{Neg}\end{array}$ \\
\hline Brain stem & & & \\
\hline $\begin{array}{l}\text { Thalamus } \\
\text { Midbrai } \\
\text { Pons } \\
\text { Medulla oblongata }\end{array}$ & $\begin{array}{l}<5 \% \\
\text { Neg } \\
\text { Neg } \\
\text { Neg }\end{array}$ & $\begin{array}{l}\text { Neg } \\
\text { Neg } \\
\text { Neg } \\
\text { Neg }\end{array}$ & $\begin{array}{l}\text { Neg } \\
\text { Neg } \\
\text { Neg } \\
\text { Neg }\end{array}$ \\
\hline Cerebellum & & & \\
\hline $\begin{array}{l}\text { Cortex } \\
\text { Molecular layer } \\
\text { Purkinje cell layer } \\
\text { Granular layer } \\
\text { Golgi neurons } \\
\text { External germinal layer } \\
\text { Cerebellar nuclei } \\
\text { Cerebellar white matter }\end{array}$ & $\begin{array}{c}42.8 \%(\text { II) } \\
\text { Neg } \\
3.2 \% \text { (II) } \\
\text { Neg } \\
100 \% \text { (II) } \\
\text { Neg } \\
\text { Neg }\end{array}$ & $\begin{array}{l}\text { Neg } \\
\text { Neg } \\
\text { Neg } \\
\text { Neg } \\
\text { n/a } \\
\text { Neg } \\
\text { Neg }\end{array}$ & $\begin{array}{l}\text { Neg } \\
\text { Neg } \\
\text { Neg } \\
\text { Neg } \\
\text { n/a } \\
\text { n/a } \\
\text { Neg }\end{array}$ \\
\hline
\end{tabular}

Neg, lack of immunostaining; (I), weak/moderate intensity; (II), strong intensity; n/a, not applicable. *Percentage of positive area compared to the total surface of subventricular zone. 
number of $\mathrm{DCX}^{+}$cells decreased drastically in adult and geriatric animals in all brain areas. In the adult dog, $\mathrm{DCX}^{+}$cells showed a marked decrease compared to the young animal and were restricted to SVZ, SGZ (Figure 1E,F), layer II paleocortex, and caudate nuclei; unexpectedly, septal nuclei showed an increase in $\mathrm{DCX}^{+}$cells. In the geriatric animal, only the SVZ maintained the presence of $\mathrm{DCX}^{+}$cells.

In the SVZ of the young dog, clusters of $\mathrm{DCX}^{+}$cells were observed, and we were unable to quantify the percentage of positive cells, so the portion of positive area compared to the total surface of this anatomical structure was calculated. This positivity decreased from the anterior to caudal and ventral parts of it. In the adult dog, below the SVZ, it was possible to identify clusters of $\mathrm{DCX}^{+}$cells in direct contact with the vessel walls (Figure 1G).

\section{Nucleostemin brain mapping}

NS immunostained cells $\left(\mathrm{NS}^{+}\right)$showed clear nucleolar immunostaining. The study of NS expression did not include a quantitative analysis of positive cells because in all areas, except for the external germinal layer of the cerebellum of the young dog, almost all nucleoli appeared stained (Figure $1 \mathrm{H}$ ).

Considering the age of the dogs, the number of $\mathrm{NS}^{+}$cells decreased moderately or disappeared in adult and geriatric animals in all brain areas. Some structures of the medulla oblongata such as reticular formation and vestibular nuclei did not show any variation in $\mathrm{NS}^{+}$cells. In the adult dog a similar number of $\mathrm{NS}^{+}$cells, compared with the young dog, were restricted to neocortex, putamen, and cerebellar nuclei; other structures, such as paleocortex, caudate and septal nuclei, and cerebellar Purkinje and Golgi cells, showed a decrease in immunostaining. In the geriatric dog, a few scattered $\mathrm{NS}^{+}$cells showing weak immunostaining were detected in the cerebrum and cerebellar Purkinje cells. In all dogs, some types of cells, such as cerebellar granules, did not express the protein.

\section{Doublecortin and nucleostemin distribution in non-nervous tissues}

No DCX immunolabeling was observed neither in mature non-nervous tissues nor proliferative tissues. Surprisingly, few $\mathrm{DCX}^{+}$cells similar to Sertoli cells, were observed in the basal compartment of the seminiferous epithelium. We found $\mathrm{NS}^{+}$cells in all adult canine non-proliferating tissue examined except for the skeletal muscle (skeletal muscle fibers and fibroblasts belonging to endomysium and perimysium). In the heart and liver we found positive nucleoli in cardiac myocytes and hepatocytes, respectively. In all tissues the nucleoli of endothelial cells were NS-positive. In the testicle we observed evident $\mathrm{NS}^{+}$immunolabeling in the Sertoli and Leydig cells. Despite the small size of the nucleoli, it was possible to discern NS expression in some spermatogonia and spermatocytes.

In second intention healing samples, the $\mathrm{NS}^{+}$immunolabeling was found in every nucleolus of epidermal cells, fibroblasts/fibrocytes, adipocytes of hypodermis, and epithelial cells of sebaceous glands, sweat glands, and external root sheath of hair follicle. Inflammatory infiltrating cells present in this sample were also positive.

\section{Discussion}

In this preliminary study, DCX and NS immunoexpression were evaluated in some canine tissues, focusing on nervous tissue along different ages to establish an age-related mapping. To our knowledge, previous studies have not been carried out on canine tissue for the two markers, except for DCX in the hippocampal region. ${ }^{31-33}$

Doublecortin gave a more selective immunostaining but not limited to the neurogenic zones, as previously described in other species. $^{8-11}$ In our dogs, SVZ showed the strongest immunopositivity, which decreased with aging; DCX labeling decreased in this area caudally and ventrally. These results are in agreement with previous results obtained in adult cat. ${ }^{8}$ In the adult dog, we noted how the $\mathrm{DCX}^{+}$cells were organized around capillary vessels similar to the typical structure of stem cells vascular niche, where clusters of cells, neural stem cells and transit-amplifying cells are in direct contact with the vessel walls. ${ }^{5,6}$

In the hippocampus of our dogs the decrease in immunostaining with age was evident and it was confined to the SGZ, coinciding with what was described earlier in $\operatorname{dog} .{ }^{31-33}$ The cerebellum of the young dog presented $100 \%$ of $\mathrm{DCX}^{+}$cells in the external germinal layer, a transitory germinal zone made up of neuronal precursors that progressively migrate across the molecular layer into the inner granular layer where they differentiate into granule cells. Our results are in accordance with other previous studies carried out on young dogs. ${ }^{34}$ In the adult and geriatric dogs this region was completely negative; after the disappearance of EGL, no neurogenic activity remained in the surface of the cerebellar cortex in the dog.

We found DCX immunolabeling in the neocortex of the young dog, especially in layer II, where the neuroblasts, migrating in the last steps of development, reside. These results are in agreement with other studies carried out in other animal species, ${ }^{8,13,16}$ but in contrast with previous findings, ${ }^{8,13}$ we observed this immunolabeling pattern only in the frontal

Table 3. Nucleostemin expression and immunostain intensity in canine brain.

\begin{tabular}{|c|c|c|c|}
\hline & Young dog & Adult dog & Geriatric dog \\
\hline \multicolumn{4}{|l|}{ Cerebrum } \\
\hline $\begin{array}{l}\text { Neocortex } \\
\text { Corpus callosum } \\
\text { Corona radiata } \\
\text { Subventricular zone } \\
\text { Ependymal layer }\end{array}$ & $\begin{array}{l}+(\mathrm{II}) \\
+(\mathrm{II}) \\
+(\mathrm{II}) \\
+(\mathrm{II}) \\
+(\mathrm{II})\end{array}$ & $\begin{array}{c}+(\mathrm{II}) \\
- \\
- \\
- \\
-\end{array}$ & $\begin{array}{c}+(\mathrm{I}) \\
- \\
- \\
- \\
-\end{array}$ \\
\hline $\begin{array}{l}\text { Basal nuclei } \\
\text { Caudate nucleus } \\
\text { Putamen nucleus } \\
\text { Septal nuclei }\end{array}$ & $\begin{array}{l}+(\text { II }) \\
+ \text { (II) } \\
+ \text { (II) }\end{array}$ & $\begin{array}{l}+(\mathrm{I}) \\
+(\mathrm{II}-\mathrm{I}) \\
+(\mathrm{I})\end{array}$ & $\begin{array}{c}- \\
- \\
+(\mathrm{I}) \\
\end{array}$ \\
\hline $\begin{array}{l}\text { Paleocortex } \\
\text { Molecular layer } \\
\text { Layer II }\end{array}$ & $\begin{array}{l}+(\text { II) } \\
+(\text { II) }\end{array}$ & $\begin{array}{c}- \\
+(\mathrm{I})\end{array}$ & $\begin{array}{c}- \\
+(\mathrm{I})\end{array}$ \\
\hline Brain stem & & & \\
\hline $\begin{array}{l}\text { Medulla oblongata } \\
\text { Reticular formation } \\
\text { Vestibular nucleus }\end{array}$ & $\begin{array}{l}+(\text { III }) \\
+(\text { II })\end{array}$ & $\begin{array}{l}+(\text { III } \\
+(\text { II })\end{array}$ & $\begin{array}{l}+(\mathrm{II}-\mathrm{I}) \\
+(\mathrm{II}-\mathrm{I})\end{array}$ \\
\hline Cerebellum & & & \\
\hline $\begin{array}{l}\text { Cortex } \\
\text { Molecular layer } \\
\text { Purkinje cell layer } \\
\text { Granular layer } \\
\text { Golgi neurons } \\
\text { External germinal layer } \\
\text { Cerebellar nuclei } \\
\text { Cerebellar white matter }\end{array}$ & $\begin{array}{l}+(\text { II }) \\
+(\text { II }) \\
\quad- \\
+(\text { II }) \\
\quad- \\
+(\text { II }) \\
+(\text { II })\end{array}$ & $\begin{array}{c}- \\
+(\mathrm{I}) \\
- \\
+(\mathrm{I}) \\
\mathrm{n} / \mathrm{a} \\
+(\mathrm{II}) \\
-\end{array}$ & $\begin{array}{c}- \\
+(\mathrm{I}) \\
- \\
- \\
\mathrm{n} / \mathrm{a} \\
\mathrm{n} / \mathrm{a} \\
-\end{array}$ \\
\hline
\end{tabular}


neocortex. These $\mathrm{DCX}^{+}$cells showed a mature neuronal morphology and probably represented neuroblasts that were differentiating into GABAergic interneurons. ${ }^{13}$

Other brain structures such as basal ganglia, especially caudate nuclei, maintained $\mathrm{DCX}^{+}$ cells into adult age, including an increase in immunostainig. In the case of septal nuclei the increased number of $\mathrm{DCX}^{+}$cells observed in the adult dog was not expected, even if the intensity of their immunostaining was weak. In both cases these findings could indicate a late migration of neurons to this area ${ }^{35}$ In the young dog, we observed cells with very weak DCX immunostaining, scattered in several brain structures, including thalamic nuclei, that might represent migrating neuroblasts that were about to lose their immunolabeling. ${ }^{10}$
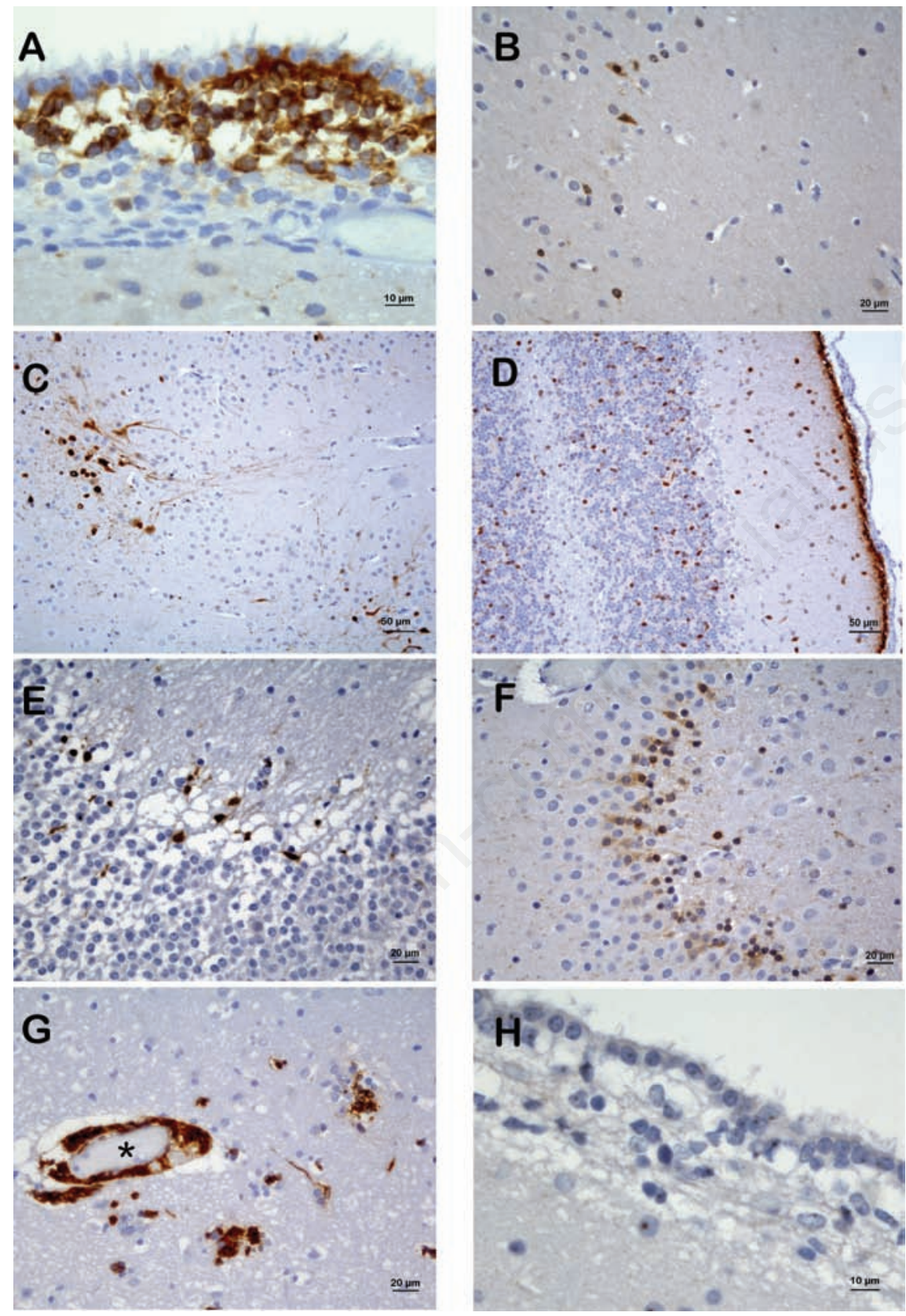

Figure 1. DCX (A-G) and NS (H) immunolabeling in brain regions. A) Magnification of $\mathrm{DCX}+$ cells in the subventricular zone of young dog. B) Scattered neurons with mature morphology in layer II of frontal neocortex in young dog. C) DCX+ neurons in the paleocortex of young dog. D) Cerebellum in young dog with the $100 \%$ of EGL cells expressing DCX. E) Comparison of the dentate gyrus immunolabeling in adult dog and (F) young dog. G) Representative structure of stem cell vascular niche $\left.{ }^{*}\right)$ below the SVZ in the adult dog. H) NS+ nucleoli in the subventricular zone of young dog.

In the case on nucleostemin we found an unexpected positivity in all brain areas in the young dog. The absence of positivity of cerebellar granules in all dogs is probably due to the inability to see the nucleoli of these neurons because of their extremely small size and the strong nuclear basophilia. Tsai and McKay ${ }^{17}$ detected $\mathrm{NS}^{+}$cells in embryonic murine brain, but studies have not been performed in normal postnatal brain. $\mathrm{NS}^{+}$cells decreased in number with age, with an irregular distribution along the brain. As adult neurons hold a well-developed rough endoplasmic reticulum, this positivity could be related to other functions of this protein, such as ribosome biogenesis. ${ }^{21}$ The physiologic reduction of protein biosynthesis with age could induce lowered expression of NS in adult and geriatric canine neurons.

In non-nervous tissue, the presence of few Sertoli-like cells $\mathrm{DCX}^{+}$could be related with the presence of neural crest originated cells as described in human and rodent normal and tumoral cases. ${ }^{36}$ Additional studies should be done on canine samples to determinate its specificity. We detected NS immunoexpression in the nucleoli of mature cells of other tissues, such as epithelial (epidermis and endothelia), glandular (sebaceous and sweat glands, hepatocytes and Leydig cells), and some muscle cells (cardiac myocytes and smooth cell fibers). Nucleoli of immature proliferating cells, such as epidermal basal cell layer, spermatogonia and spermatocytes, were also $\mathrm{NS}^{+}$. Our results are in agreement with those previously described in these tissues in other species (human, mouse and rat). ${ }^{17,23,24,37}$ The lack of immunostaining in canine skeletal muscle samples could be due to technical conditions, as in another published study, where, using low sensitivity techniques such as northern blot, the authors were unable to detect NS in this tissue, while with RT-PCR they could isolate its mRNA but only in small quantity. ${ }^{38}$ Other $\mathrm{NS}^{+}$proliferative cells detected by us on an adult canine skin biopsy with granulation tissue might be related to other recently described functions of NS, such as cellular proliferation $^{19}$ and maintenance of telomere length. ${ }^{20}$ Additionally, NS has been described in human and rodent neoplasms, ${ }^{22-30}$ as an indicator of nucleolar activity. Our findings could well corroborate all of these functions of NS in all studied canine tissues.

In conclusion, we can affirm that doublecortin expression is associated with neurogenesis and neuronal migration in canine brain, but it is not exclusive for neural stem cells. Our results showed that nucleostemin is not a specific marker of stem cells or progenitor cells in canine nervous tissue. It would be interesting to determine its role in cell proliferation and development of neoplasm. Additional studies should be carried out to clarify its role as a possible stem cell proliferation marker in canine neoplasia. 


\section{References}

1. Landgren H, Curtis MA. Locating and labeling neural stem cells in the brain. $\mathrm{J}$ Cell Physiol 2011;226:1-7.

2. Merkle FT, Tramontin AD, Garcia-Verdugo JM, Alvarez-Buylla A. Radial glia give rise to adult neural stem cells in the subventricular zone. Proc Natl Acad Sci USA 2004;101:17528-32.

3. Oboti L, Peretto P, De Marchis S, Fasolo A. From chemical neuroanatomy to an understanding of the olfactory system. Eur $\mathrm{J}$ Histochem 2011;55:e35.

4. Doetsch F, Caille I, Lim DA, GarciaVerdugo JM, Alvarez-Buylla A. Subventricular zone astrocytes are neural stem cells in the adult mammalian brain. Cell 1999; 97:703-16.

5. Doetsch F. The glial identity of neural stem cells. Nat Neurosci 2003;6:1127-34.

6. Doetsch F. A niche for adult neural stem cells. Curr Opin Genet Dev 2003;13 543-50.

7. Horesh D, Sapir T, Francis F, Wolf SG, Caspi M, Elbaum M, et al. Doublecortin, a stabilizer of microtubules. Hum Mol Genet 1999;8:1599-610.

8. Cai Y, Xiong K, Chu Y, Luo DW, Luo XG, Yuan XY, et al. Doublecortin expression in adult cat and primate cerebral cortex relates to immature neurons that develop into GABAergic subgroups. Exp Neurol 2009;216:342-56.

9. Nacher J, Crespo C, McEwen BS. Doublecortin expression in the adult rat telencephalon. Eur J Neurosci 2001;14: 629-44.

10. Brown JP, Couillard-Despres S, CooperKuhn CM, Winkler J, Aigner L, Kuhn HG. Transient expression of doublecortin during adult neurogenesis. J Comp Neurol 2003;467:1-10.

11. Yang HK, Sundholm-Peters NL, Goings GE, Walker AS, Hyland K, Szele FG. Distribution of doublecortin expressing cells near the lateral ventricles in the adult mouse brain. J Neurosci Res 2004;76:28295.

12. Bernier PJ, Bedard A, Vinet J, Levesque M, Parent A. Newly generated neurons in the amygdala and adjoining cortex of adult primates. Proc Natl Acad Sci USA 2002;99: 11464-9.

13. Xiong K, Luo DW, Patrylo PR, Luo XG, Struble RG, Clough RW, et al. Doublecortin-expressing cells are present in layer II across the adult guinea pig cerebral cortex: partial colocalization with mature interneuron markers. Exp Neurol 2008;211:271-82.

14. Luzzati F, Bonfanti L, Fasolo A, Peretto P.
DCX and PSA-NCAM expression identifies a population of neurons preferentially distributed in associative areas of different pallial derivatives and vertebrate species. Cereb Cortex 2009;19:1028-41.

15. Amrein I, Slomianka L. A morphologically distinct granule cell type in the dentate gyrus of the red fox correlates with adult hippocampal neurogenesis. Brain Res 2010;1328:12-24.

16. Bloch J, Kaeser M, Sadeghi Y, Rouiller EM, Redmond DE, Brunet JF. Doublecortin-positive cells in the adult primate cerebral cortex and possible role in brain plasticity and development. J Comp Neurol 2011; 519:775-89.

17. Tsai RY, McKay RD. A nucleolar mechanism controlling cell proliferation in stem cells and cancer cells. Genes Dev 2002; 16:2991-3003.

18. Tsai RY, Meng L. Nucleostemin: a latecomer with new tricks. Int J Biochem Cell Biol 2009;41:2122-4.

19. Beekman C, Nichane M, De Clercq S, Maetens M, Floss T, Wurst W, et al. Evolutionarily conserved role of nucleostemin: controlling proliferation of stem/progenitor cells during early vertebrate development. Mol Cell Biol 2006;26: 9291-301.

20. Zhu Q, Yasumoto H, Tsai RY. Nucleo stemin delays cellular senescence and negatively regulates TRF1 protein stability. Mol Cell Biol 2006;26:9279-90.

21. Romanova L, Grand A, Zhang L, Rayner S, Katoku-Kikyo N, Kellner S, et al. Critical role of nucleostemin in pre-rRNA processing. J Biol Chem 2009;284:4968-77.

22. Liu SJ, Cai ZW, Liu YJ, Dong MY, Sun LQ, $\mathrm{Hu} \mathrm{GF}$, et al. Role of nucleostemin in growth regulation of gastric cancer, liver cancer and other malignancies. World J Gastroenterol 2004;10:1246-9.

23. Fan Y, Liu Z, Zhao S, Lou F, Nilsson S, Ekman P, et al. Nucleostemin mRNA is expressed in both normal and malignant renal tissues. Br J Cancer 2006;94:165862.

24. Lacina L, Smetana K, Dvorankova B, Stork J, Plzakova Z, Gabius HJ. Immunocyto- and histochemical profiling of nucleostemin expression: marker of epidermal stem cells? J Dermatol Sci 2006;44:73-80.

25. Cada Z, Boucek J, Dvorankova B, Chovanec M, Plzak J, Kodets R, et al. Nucleostemin expression in squamous cell carcinoma of the head and neck. Anticancer Res 2007;27:3279-84.

26. Ye F, Zhou C, Cheng Q, Shen J, Chen H. Stem-cell-abundant proteins Nanog, Nucleostemin and Musashil are highly expressed in malignant cervical epithelial cells. BMC Cancer 2008;8:108.
27. Kawashima M, Kawakita T, Yoshida S, Shimmura S, Tsubota K. Nucleostemin as a possible progenitor marker of corneal epithelial cells. Mol Vis 2009;15:1162-8.

28. Nikpour P, Mowla SJ, Jafarnejad SM, Fischer U, Schulz WA. Differential effects of nucleostemin suppression on cell cycle arrest and apoptosis in the bladder cancer cell lines 5637 and SW1710. Cell Prolif 2009;42:762-9.

29. Zhang G, Zhang Q, Zhang Q, Yin L, Li S, Cheng $\mathrm{K}$, et al. Expression of nucleostemin, epidermal growth factor and epidermal growth factor receptor in human esophageal squamous cell carcinoma tissues. J Cancer Res Clin Oncol 2010;136: 587-94.

30. Yoshida R, Fujimoto T, Kudoh S, Nagata M, Nakayama H, Shinohara M, et al. Nucleostemin affects the proliferation but not differentiation of oral squamous cell carcinoma cells. Cancer Sci 2011;102: 1418-23.

31. Siwak-Tapp CT, Head E, Muggenburg BA, Milgram NW, Cotman CW. Neurogenesis decreases with age in the canine hippocampus and correlates with cognitive function. Neurobiol Learn Mem 2007;88: 249-59.

32. Pekcec A, Baumgartner W, Bankstahl JP, Stein VM, Potschka H. Effect of aging on neurogenesis in the canine brain. Aging Cell 2008;7:368-74.

33. Hwang IK, Yoo KY, Park OK, Choi JH, Lee $\mathrm{CH}$, Won MH. Comparison of density and morphology of neuroblasts in the dentate gyrus among variously aged dogs, German shepherds. J Vet Med Sci 2009;71:211-5.

34. Ponti G, Peretto P, Bonfanti L. A subpial, transitory germinal zone forms chains of neuronal precursors in the rabbit cerebellum. Dev Biol 2006;294:168-80.

35. Fox MW, Inman OR, Himwich WA. The postnatal development of neocortical neurons in the dog. J Comp Neurol 1966; 127:199-206.

36. Kobayashi K, Jakt LM, Nishikawa SI. Epigenetic regulation of the neuroblastoma genes, Arid3b and Mycn. Oncogene 2012; doi: 10.1038/onc.2012.285. [Epub ahead of print].

37. Siddiqi S, Gude N, Hosoda T, Muraski J, Rubio M, Emmanuel G, et al. Myocardial induction of nucleostemin in response to postnatal growth and pathological challenge. Circ Res 2008;103:89-97.

38. Sijin L, Ziwei C, Yajun L, Meiyu D, Hongwei $\mathrm{Z}$, Guofa $\mathrm{H}$, et al. The effect of knocking-down nucleostemin gene expression on the in vitro proliferation and in vivo tumorigenesis of HeLa cells. $\mathbf{J}$ Exp Clin Cancer Res 2004;23:529-38. 